\title{
PENGARUH MODEL PEMBELAJARAN BERBASIS MASALAH TERHADAP KETERAMPILAN BERPIKIR KRITIS SISWA PADA KELAS V SD
}

\author{
Rotua Batubara ${ }^{1}$, Patri Janson Silaban ${ }^{2}$, Anton Sitepu ${ }^{3}$ \\ 1,2,3 Universitas Katolik Santo Thomas, Medan, Indonesia \\ ${ }^{1}$ rotua_batubara@gmail.com, ${ }^{2}$ patri.jason.silaban@gmail.com, 3anton_sitepu@gmail.com
}

\begin{abstract}
ABSTRAK
Metode penelitian yang penulis gunakan dalam penelitian ini yaitu metode deskriptik analitik. Populasi dalam penelitian ini adalah seluruh siswa kelas V B semester II (Genap) di SD Negeri 067245 Bunga Asoka Tahun Pembelajaran 2020/2021 yang berjumlah 29 orang. Untuk mengetahui kemampuan awal siswa, penelitian melakukan Pre Test dengan rata-rata 63.72 dapat dikatakan kemampuan awalnya cukup. Hasil dari Post Test tersebut memiliki peningkatan dari hasil Pre Test yang diberikan sebelumnya. Hasil Post Test yang sudah diujikan sebesar 80.55 dapat dikatakan tingkat keberhasilan keterampilan berpikir kritisnya meningkat.Hasil koefisien korelasi membuktikan bahwa adanya pengaruh model pembelajaran Berbasis Masalah (X) terhadap keterampilan berpikir kritis (Y) dengan hasil $r_{\text {hitung }}>r_{\text {tabel }}$ dengan hasil $0.852>0.367$. Pada uji hipotesis dengan menggunakan uji-t dari perhitungan data yang dilakukan, hasil pengujian yaitu $t_{\text {hitung }}>t_{\text {tabel }}$ hasilnya $8.478>1.703$ dengan taraf signifikan $(\alpha=0.05)$. Berdasarkan hasil data yang diperoleh dari penelitian di SD Negeri 067245 Bunga Asoka dapat dikatakan bahwa dengan model pembelajaran Berbasis Masalah sangat efektif dalam pembelajaran tematik di kelas.
\end{abstract}

Kata Kunci: model pembelajaran berbasis masalah, keterampilan berpikir kritis

\section{THE INFLUENCE OF PROBLEM-BASED LEARNING MODEL ON STUDENT'S CRITICAL THINKING SKILLS AT GRADE V ELEMENTARTY SCHOOLS}

\begin{abstract}
The research utilized the descriptive-analytical method. The population in this study were all students at grade VB in the even semester at SD Negeri 067245 Bunga Asoka the academic year 2020/2021, totaling 29 people. To determine the students' initial ability, the researchers conducted a Pre Test with an average of 63.72. It was found that the initial ability was sufficient. The results of the Post Test increased from the results of the Pre Test given previously. The results of the Post Test were 80.55; thus, the success rate of critical thinking skills increased. The results of the correlation coefficient proved that there was an effect of Problem-Based learning model $(X)$ on critical thinking skills $(Y)$ with $r_{\text {count }}>r_{\text {table }}$ was $0.852>0.367$. In testing the hypothesis by using the $t$-test, it was found that $t_{\text {count }}>t_{\text {table }}$ or $8.478>1.703$, with a significant level of $\left.\alpha=0.05\right)$. Based on the results of the data obtained from research at SD Negeri 067245 Bunga Asoka, it was said that the Problem-Based learning model was very effective in thematic learning in the classroom.
\end{abstract}

Keywords: problem based learning model, critical thinking skills

\begin{tabular}{|c|c|c|}
\hline Submitted & Accepted & Published \\
\hline 23 Juli 2021 & 19 Oktober 2021 & 24 November 2021 \\
\hline
\end{tabular}

\begin{tabular}{|l|c|c|}
\hline Citation & $:$ & $\begin{array}{r}\text { Batubara, R., Silaban, P.J., \& Sitepu, A. (2021). Pengaruh Model Pembelajaran Berbasis Masalah Terhadap Keterampilan } \\
\text { Berpikir Kritis Siswa Pada Kelas V SD Jurnal PAJAR (Pendidikan dan Pengajaran), 5(6), 1626-1637. DOI : } \\
\text { http://dx.doi.org/10.33578/pjr.v5i6.8483. }\end{array}$ \\
\hline
\end{tabular}

\section{PENDAHULUAN}

Pendidikan adalah suatu proses pembelajaran pengetahuan, keterampilan, dan kebiasaan sekumpulan manusia yang diwariskan dari satu genereasi ke generasi selanjutnya melalui pengajaran, pelatihan, dan penelitian. Pendidikan bukan hanya dilaksanakan dalam bentuk formal melainkan dilakukan dalam bentuk informal juga. Akan tetapi banyak hal dapat merubah proses belajar baik dalam bentuk sarana dan prasarana serta kurikulum yang semakin pesat perkembangannya. Pendidikan memberikan kemungkinan pada siswa untuk memperoleh kesempatan, harapan, dan pengetahuan agar dapat hidup secara lebih baik. Besarnya kesempatan dan harapan sangat bergantung pada kualitas pendidikan yang ditempuh. Pendidikan juga dapat menjadi kekuatan untuk melakukan perubahan agar sebuah kondisi menjadi lebih baik. Pendidikan yang berkualitas tentunya melibatkan siswa untuk aktif belajar dan mengarahkan 
terbentuknya nilai-nilai yang dibutuhkan oleh siswa dalam menempuh kehidupan (Sani, 2018: $1)$.

Pendidikan yang saat ini dilakukan di Indonesia dalam proses belajar mengajar di sekolah masih banyak yang menggunakan cara lama dalam penyampaian materi, dimana guru menjelaskan dan siswa hanya sebagai pendengar dan kemudian mengerjakan tugas sehingga pembelajaran kurang aktif dan efektif dan hasil belajar siswa tidak mencapai standar yang telah ditetapkan. Hal ini menyebabkan kondisi pendidikan indonesia masih buruk dan perlu bantuan dorongan dari pihak pemerintahan dan juga pihak pendidikan (Manullang, 2021: 470). Untuk mencapai tujuan pendidikan tersebut, maka pemerintah berupaya membantu untuk seperti memberlakukan kurikulum 2013, dan juga penggunaan media dan bahan ajar dalam proses pembelajaran. Pergantian Kurikulum 2004 menjadi Kurikulum 2013 sudah berlangsung beberapa tahun. Dengan tuntutan pemerintah bahwa setiap sekolah harus menerapkan kurikulum 2013 sesuai keputusan dari Kemendikbud. Pada kurikulum 2013 ini lebih menekankan pada karakter dan mampu menciptakan manusia yang bermartabat, beradab, berbudaya, berkarakter, beriman, dan bertakwa pada Tuhan Yang Maha Esa, berakhlak mulia, sehat, berilmu, cakap, kreatif, mandiri dan bertanggung jawab.

Berdasarkan kurikulum tersebut maka siswa dituntut lebih aktif dan kreatif lagi dan guru sebagai fasilitator dalam pembelajaran. Dalam pembelajaran ini yang dimaksud adalah guru hanya berperan sebagai pemberi arahan/mengarahkan proses pembelajaran dan siswa berperan aktif, kreatif, serta dapat memecahkan masalah. Tetapi guru juga harus lebih kreatif dari pada siswa baik dalam penggunaan media pembelajaran dan metode pembelajaran. Peran guru di ruangan kelas bukan hanya menjadi penyaji pelajaran yang akan dipelajari oleh siswa, melainkan mengajarkan kepada siswa tentang cara mempelajari sesuatu dengan efektif. Selain itu membimbing dan melatih siswa untuk mengembangkan keterampilan yang dimiliki siswa tersebut. (Silaban, 2019: 109)
Sesuai dengan hasil observasi di sekolah SD Negeri 067245 Bunga Asoka pada kelas V peneliti menemukan kondisi dimana kurangnya keterampilan berpikir kritis siswa serta pemahaman terhadap pembelajaran yang disampaikan guru, kemampuan berpikir kritis sangat perlu dikembangkan demi keberhasilan dalam pendidikan dan dalam kehidupan bermasyarakat. Keterampilan berpikir kritis dapat dikembangkan atau diperkuat, melalui proses pembelajaran, proses pembelajaran yang dapat mendorong diskusi pada saat pembelajaran, memberikan kesempatan berpendapat kepada siswa, dan juga memberikan kesempatan kepada siswa untuk mengeluarkan ide-ide mereka pada saat proses pembelajaran. Siswa juga kurang aktif selama proses pembelajaran berlangsung. Ketika pembelajaran berlangsung siswa terlihat tidak aktif mengambil bagian dalam pembelajaran, ketika guru memberikan suatu pertanyaan atau menanyakan materi yang telah disampaikan kebanyakan siswa diam dan tidak menjawab. keaktifan siswa dalam menjalani proses belajar mengajar merupakan salah satu kunci keberhasilan pencapaian tujuan pembelajaran. Dalam hal ini guru juga dituntut untuk menumbuhkan keberanian siswa agar tidak takut untuk bertanya dan menjawab pertanyaan temannya. Karena itu, siswa perlu dibiasakan berani mengambil keputusan untuk bertanya ataupun menjawab pertanyaan guru ataupun pertanyaan dari temannya. Sehingga semua nya dapat aktif dan mengambil bagian selama proses pembelajaran berlangsung.

Penggunaan model pembelajaran yang kurang bervariasi. Hal ini akan membuat siswa menjadi bosan dalam proses pembelajaran dan juga suasana belajar menjadi kurang menyenangkan. Penggunaan model pembelajaran merupakan kemampuan yang dimiliki oleh guru. Guru diharapkan mampu memilih dan menggunakan model pembelajaran sesuai dengan materi yang akan disampaikan. "Setiap model pembelajaran memiliki kelebihan dan kelemahan dilihat dari berbagai sudut, namun yang penting bagi guru metode mana pun yang digunakan harus jelas tujuan yang akan dicapai" (Rusman, 2019: 78). Karena idealnya seorang guru harus bisa memvariasikan penggunaan model pembelajaran 
di dalam kelas seperti model ceramah dipadukan dengan tanya jawab dan penugasan atau model diskusi dengan pemberian tugas dan seterusnya. Hal ini dimaksudkan untuk menjembatani kebutuhan siswa dan menghindari terjadinya kejenuhan yang dialami siswa.

Peran guru dalam pembelajaran itu adalah sebagai fasilitator, bukan sebagai sumber belajar. Hal ini dapat terlihat bahwa pembelajaran masih cenderung berpusat pada guru, disini siswa lah yang menyelesaikan permasalahan yang diberikan dalam proses pembelajaran, bukan menerima pengetahuan. Dan di dalam proses belajar ini siswa menyelesaikan masalah, bukan menguasai pengetahuan (Sani, 2018: 3). Artinya di dalam proses pembelajaran itu siswa lah yang harus lebih aktif, mereka harus mampu menemukan dan memecahkan masalah, lalu guru akan memfasilitasi dan mengawasi proses pembelajaran, sehingga pembelajaran itu tidak cenderung berpusat pada guru melainkan berpusat pada siswa.

Maka untuk mengatasi masalah tersebut guru dituntut untuk terampil dalam menerapkan model pembelajaran berbasis masalah. Model pembelajaran berbasis masalah merupakan pembelajaran yang penyampaiannya dilakukan dengan cara menyajikan suatu permasalahan, mengajukan pertanyaan-pertanyaan, memfasilitasi penyelidikan, dan membuka dialog. Permasalahan yang dikaji hendaknya merupakan permasalahan kontekstual yang ditemukan oleh peserta didik dalam kehidupan sehari-hari. Permasalahan harus dipecahkan dengan menerapkan beberapa konsep dan prinsip yang secara simultan dipelajari dan tercakup dalam kurikulum mata pelajaran (Sani, 2018: 127). Pembelajaran Berbasis Masalah merupakan inovasi dalam pembelajaran karena dalam PBM kemampuan berpikir siswa betulbetul dioptimalisasikan melalui proses kerja kelompok atau tim yang sistematis, sehingga siswa dapat memberdayakan, mengasah, menguji, dan mengembangkan kemampuan berpikirnya secara berkesinambungan.

Maka model ini sangat menarik diterapkan dalam proses pembelajaran karena model ini memiliki kelebihan dimana model ini melibatkan siswa untuk belajar menyelesaikan suatu masalah dunia nyata yang bersifat kontekstual dan sekaligus belajar untuk mengetahui pengetahuan yang diperlukan, sehingga keterampilan berpikir kritis pada siswa meningkat.

\section{KAJIAN TEORETIS}

\section{Keterampilan Berpikir Kritis}

Berpikir tidak terlepas dari aktivitas manusia, karena berpikir merupakan ciri yang membedakan antara manusia dengan makhluk hidup lainnya. Berpikir kritis merupakan salah satu bentuk keterampilan tingkat tinggi yang sangat penting dimilki setiap manusia, karena akan berdampak positif bagi arah kehidupannya dalam meraih harapan dan cita-cita hidupnya. Setiap manusia yang tidak memiliki keterampilan dalam berpikir kritis dalam hidupnya akan mendapatkan kendala-kendala dalam hal menyelesaikan permasalahan hidup yang dialaminya. Berpikir kritis adalah bepikir secara beralasan dan reflektif dengan menekankan pembuatan keputusan tentang apa yang harus dipercayai atau dilakukan Mustaji (Surip, 2014: 1).

Keterampilan berpikir kritis adalah suatu kegiatan melalui cara berpikir tentang ide atau gagasan yang berhubung dengan konsep yang diberikan atau masalah sebagai kegiatan menganalisis idea atau gagasan ke arah yang lebih spesifik, membedakannya secara tajam, memilih, mengidentifikasi, mengkaji dan mengembangkannya ke arah yang lebih sempurna (Susanto, 2018: 121). Cara berpikir secara sistematis dengan langkah yang benar melauli proses menganalisa, memecahkan masalah untuk menggali kejelasan suatu informasi yang disampaikan sehingga ditemukan kebenaran dari informasi tersebut

Keterampilan berpikir kritis adalah salah satu dari keterampilan berpikir tingkat tinggi. Keterampilan berpikir kritis banyak digunakan dalam kehidupan sehari-hari, karenanya, mempelajari keterampilan berpikir kritis bagi siswa, atau mengajarkan keterampilan berpikir kritis bagi guru sangat penting. Berpikir kritis adalah mengevaluasi konklusi-konklusi (kesimpulan-kesimpulan) berdasarkan pengujian terhadap suatu masalah, kejadian, atau pemecahan masalah secara logis dan sistematis (Surip, 2014: $31)$. 
Dalam bidang pendidikan, berpikir kritis dapat membantu seseorang dalam meningkatkan pemahaman materi yang dipelajari dengan mengevaluasi secara kritis argumen pada buku teks, jurnal, teman diskusi, termasuk argumentasi pengajar dalam kegiatan pembelajaran. Jadi berpikir kritis dalam pendidikan merupakan kompetensi yang akan dicapai serta alat yang diperlukan dalam mengkonstruksi pengetahuan. Berpikir yang ditampilkan dalam berpikir kritis sangan tertib dan sistematis. Kemampuan berpikir kritis sangat perlu dikembangkan demi keberhasilan dalam pendidikan dan dalam kehidupan bermasyarakat. Keterampilan berpikir kritis dapat dikembangkan atau diperkuat melalui proses pembelajaran.

\section{Model Pembelajaran Berbasis Masalah}

Model pembelajaran berbasis masalah adalah pembelajaran yang menggunakan masalah nyata yang tidak terstruktur dan bersifat terbuka sebagai konteks bagi peserta didik untuk mengembangkan keterampilan menyelesaikan masalah dan berpikir kritis serta sekaligus membangun pengetahuan baru.

Model pembelajaran berbasis masalah adalah suatu model pembelajaran yang melibatkan peserta didik untuk memecahkan suatu masalah melalui tahap-tahap metode ilmiah sehingga peserta didik dapat mempelajari pengetahuan yang berhubungan dengan masalah tersebut dan sekaligus memiliki keterampilan untuk memecahkan masalah. Perubahan cara pandang terhadap siswa sebagai objek menjadi subjek dalam proses pembelajaran menjadi titik tolak banyak ditemukannya berbagai pendekatan pembelajaran yang inovatif.

Model pembelajaran berbasis masalah merupakan inovasi dalam pembelajaran karena dalam PBM kemampuan berpikir kritis siswa betul-betul dioptimalkan melalui proses kerja kelompok atau tim yang sistematis, sehingga siswa dapat memberdayakan, mengasah, menguji dan mengembangkan kemampuan berpikirnya secara berkesinambungan Tan (Rusman, 2019: 229). Di dalam proses belajar yang akan berlangsung siswa akan di tuntut untuk berpikir kritis dan mengekspresikan ide-ide yang mereka miliki baik itu secara individu ataupun kelompok.
Model pembelajaran berbasis masalah atau Problem Based Learning adalah suatu model pembelajaran yang melibatkan peserta didik untuk memecahkan suatu masalah melalui tahap-tahap metode ilmiah sehingga peserta didik dapat mempelajari pengetahuan yang berhubungan dengan masalah tersebut dan sekaligus memiliki keterampilan untuk memecahkan masalah (Fathurrohman, 2015: 113).

Pembelajaran Berbasis Masalah (PBM) adalah model pengajaran yang bercirikan adanya permasalahan nyata sebagai konteks untuk para peserta didik belajar berpikir kritis dan keterampilan memecahkan masalah serta memperoleh pengetahuan Duch (Shoimin, 2019: 130). Di dalam proses pembelajaran siswa akan dihadapkan pada suatu permasalahan yang pernah mereka alami atau masalah yang ada disekitar mereka, dan mereka akan mencari solusi atau memecahkan permasalahan yang telah diberikan.

\section{METODE PENELITIAN}

\section{Pendekatan Penelitian dan Metode Penelitian}

Sesuai dengan tujuan penelitian dan hipotesis yang diajukan, maka penelitian ini menggunakan pendekatan penelitian kuantitatif. Dilihat dari permasalahannya, maka penelitian ini jenisnya adalah Kuantitatif dengan Metode penelitian deskriptik analitik. Dalam penelitian tidak terlepas dari metode penelitian karena dari metode penelitian dapat diketahui apa tujuan peneliti. Menurut Sugiyono (2018: 13)"Metode penelitian adalah cara ilmiah untuk mendapatkan data dengan tujuan dan kegunaan tertentu". Metode penelitian yang penulis gunakan dalam penelitian ini yaitu metode deskriptik analitik dengan tujuan untuk menganalisis data sampel dan hasilnya diberlakukan untuk populasi.Desain penelitian ini digunakan untuk mengetahui pengaruh antara variabel model pembelajaran berbasis masalah $(\mathrm{X})$ terhadap keterampilan berpikir kritis siswa di kelas V (Y). Lokasi penelitian adalah tempat yang digunakan peneliti dalam melakukan penelitian dan memperoleh data yang diperlukan oleh peneliti. Penelitian ini akan dilaksanakan pada siswa kelas V B SD Negeri 067245 Bunga Asoka. Yang beralamat di jl. Bunga Asoka Kecamatan Medan Selayang Kota Medan. 
Waktu pelaksanaan penelitian ini akan dilakukan pada April sampai pelaksanaan penelitian selesai.

\section{Populasi dan Sampel Penelitian}

Pupulasi dalam penilitian ini merupakan seluruh siswa kelas V B semester II (Genap) di SD Negeri 067245 Bunga Asoka Tahun Pembelajaran 2020/2021 yang berjumlah 29 orang.

Dalam penelitian kuantitatif, sampel adalah bagian dari jumlah dan karakteristik yang dimiliki oleh populasi tersebut. Bila populasi besar, dan peneliti tidak mungkin mempelajari semua yang ada pada populasi, misalnya karena keterbatasan dana, tenaga dan waktu, maka peneliti dapat menggunakan sampel yang diambil dari populasi itu. Apa yang dipelajari dari sampel itu, kesimpulannya akan diberlakukan untuk populasi. Dijelaskan bahwa dikatakan simple (sederhana) karena pengambilan anggota sampel dari populasi dilakukan secara acak tanpa memperhatikan strata yang ada dalam populasi itu (Sugiyono, 2018: 82). Pengambilan sampel dalam penelitian ini dilakukan dengan cara Simple Random Sampling. Dikatakan simple (sederhana) karena pengambilan anggota sampel dari populasi dilakukan secara acak tanpa memperhatikan strata yang ada dalam populasi itu. Jadi yang menjadi sampel dalam penelitian ini adalah kelas V B SD Negeri 067245 Bunga Asoka yang berjumlah 29 orang.

\section{Teknik Pengolahan (Analisis) Data Uji Koefisien Korelasi}

Untuk mengetahui ada atau tidaknya pengaruh antara variabel bebas (X) dengan variabel terikat (Y). Peneliti menggunakan rumus Korelasi Pearson Product moment sebagai berikut

$$
\mathrm{r}_{\mathrm{xy}}=\frac{\mathrm{N} \sum \mathrm{XY}-\left(\sum \mathrm{X}\right)\left(\sum \mathrm{Y}\right)}{\sqrt{\left\{\mathrm{N} \sum \mathrm{X}^{2}-\left(\sum \mathrm{X}^{2}\right)\right\}\left\{\left(\mathrm{N} \sum \mathrm{Y}^{2}-\left(\sum \mathrm{Y}^{2}\right)\right\}\right.}}
$$

(Arikunto, 2018: 213)

Keterangan:

$\mathrm{r}_{\mathrm{xy}}=$ Koefisien korelasi Product moment antara variabel $\mathrm{x}$ dan $\mathrm{y}$

$N=$ Number of caces (Jumlah responden/banyak siswa peserta test)
$\Sigma \mathrm{X}=$ Skor item

$\Sigma \mathrm{Y}=$ Skor total seluruh siswa

$\Sigma \mathrm{XY}=$ Jumlah hasil perkalian antara skor " $\mathrm{X}$ " dan skor "Y"

\section{Uji Hipotesis}

Prosedur yang memungkinkan peneliti menerima atau menolak hipotesis nol, atau data sampel yang berbeda nyata dari hasil yang diharapkan disebut pengujian hipotesis (Margono, 2018: 194). Pada penelitian ini, uji t digunakan untuk mengetahui sejauh mana variabel model pembelajaran berbasis masalah mampu menjelaskan pengaruh terhadap keterampilan berpikir siswa siswa. Untuk mengetahui pengaruh setiap variabel peneliti menggunakan uji t dengan rumus uji signifikansi korelasi product moment. Dengan bantuan program SPSS Versi 22.0. Adapun rumus menurut (Sugiyono, 2018:184) sebagai berikut :

$$
\mathrm{t}=\frac{\mathrm{r} \sqrt{\mathrm{n}-1}}{\sqrt{1-\mathrm{r}^{2}}}
$$

Hipotesis diterima, jika $t_{\text {hitung }} \geq t_{\text {tabel }}$ begitu juga sebaliknya jika $t_{\text {hitung }} \leq t_{\text {tabel }}$ ditolak.

\section{HASIL DAN PEMBAHASAN \\ Hasil Pre Test Kelas VB}

Pada kelas V-B yang berjumlah 29 siswa. Peneliti terlebih dahulu menggunakan tindakan awal atau pretes sebelum mulai pembelajaran untuk mengetahui kemampuan siswa. Hasil Pre Test yang telah dilaksanakan siswa menunjukkan bahwa kemampuan keterampilan berpikir kritis siswa pada subtema manusia dan lingkungan masih dikatakan cukup.

Kemampuan hasil belajar siswa dalam memahami materi dari sub tema manusia dan lingkungan. Dari nilai Pre Test siswa kelas V B, yang mendapatkan nilai yang tidak tuntas berjumlah 19 siswa sedangkan yang mendapatkan nilai tuntas 10 siswa. Nilai rata-rata Pre Test 63,72. Selanjutnya untuk lebih jelas mengenai hasil nilai Pre Test kelas V B, dibawah ini tabel frekuensi secara ringkas dapat dilihat sebagai berikut: 
Tabel 2. Distribusi Frekuensi Nilai Pre Test kelas VB

\begin{tabular}{ccccc}
\hline No & Nilai & Frekuensi & Persentase & Kategori \\
\hline 1 & $38-46$ & 4 & $13.8 \%$ & Gagal \\
2 & $47-55$ & 2 & $6.9 \%$ & Kurang \\
3 & $56-64$ & 10 & $34.5 \%$ & Cukup \\
4 & $65-73$ & 7 & $24.15 \%$ & Baik \\
5 & $74-82$ & 3 & $10.35 \%$ & Baik \\
6 & $83-91$ & 3 & $10.35 \%$ & Baik Sekali \\
& Jumlah & 29 & $100 \%$ & \\
\end{tabular}

Berdasarkan data di atas dapat diketahui nilai Pre Test siswa yaitu: 4 responden memperoleh skor disekitar 38-46 sebesar 13.8\%, 2 responden memperoleh skor disekitar 47-55 sebesar $6.9 \%, 10$ responden memperoleh skor sekitar $56-64$ sebesar $34.5 \%, 7$ responden memperoleh skor sekitar $65-73$ sebesar $24.15 \%, 3$ responden memperoleh skor 74-82 sebesar $10.35 \%, 3$ responden memperoleh skor sekitar 8391 sebesar $10.35 \%$. Hasil distribusi frekuensi Pre Test yang disajikan pada tabel digambarkan dalam histogram sebagai berikut:

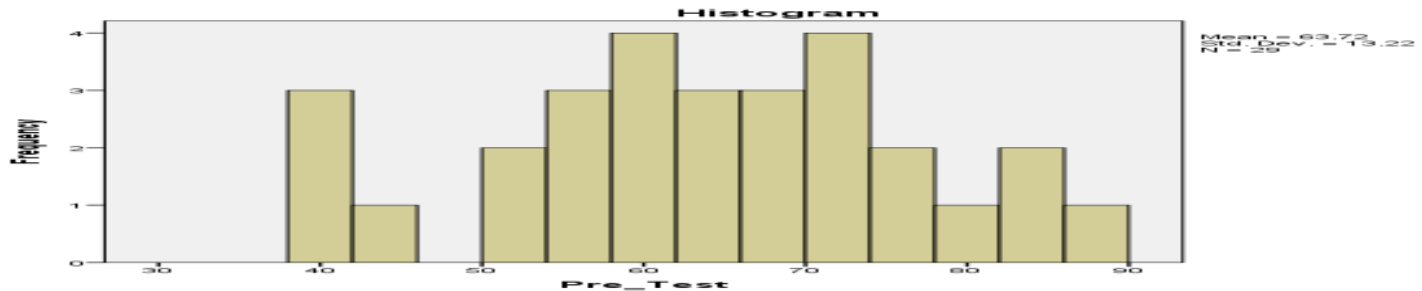

Gambar 1. Histogram Distribusi Frekuensi Nilai Pre Test

Berdasarkan tabel distribusi frekuensi nilai Pre Test kelas V diperoleh nilai tertinggi adalah 88 dan nilai terendah 40 diperoleh rata-rata (mean) sebesar 63.72 dan standar deviasi sebesar 13.22. Siswa yang memperoleh nilai diatas ratarata (mean) sebanyak 10 orang dengan presentase $34.5 \%$ dan siswa yang memperoleh nilai dibawah rata-rata (mean) sebanyak 19 orang dengan presentase $65.55 \%$. Dengan presentase tertinggi sebesar $34.5 \%$ dan persentase terendah sebesar $6.9 \%$.

\section{Hasil Post Test Kelas V B}

Pada akhir pembelajaran, semua materi pelajaran diajarkan dengan menggunakan model pembelajaran Berbasis Masalah, selanjutnya peneliti memberikan Post Test yang bertujuan untuk mengetahui tingkat keberhasilan atas tindakan yang diberikan bahwa rata-rata nilai siswa kelas V B dengan menggunakan Post Test yaitu 80,55. Nilai Post Test dilaksanakan setelah pembelajaran atau menjelaskan materi dengan menggunakan model pembelajaran Berbasis Masalah. Terdapat nilai yang tuntas sebanyak 25 siswa sedangakan nilai yang tidak tuntas sebanyak 4 siswa. untuk lebih jelas mengenai hasil nilai Post Test kelas V B, dibawah ini tabel frekuensi secara ringkas dapat dilihat sebagai berikut: 
Jurnal PAJAR (Pendidikan dan Pengajaran)

Volume 5 Nomor 6 November | ISSN Cetak : 2580 - 8435| | ISSN Online : 2614 - 1337

DOI : http://dx.doi.org/10.33578/pjr.v5i6.8483

Tabel 3. Distribusi Frekuensi Nilai Post Test kelas V B

\begin{tabular}{ccccc}
\hline No & Nilai & Frekuensi & Persentase & Kategori \\
\hline 1 & $59-65$ & 1 & $3.45 \%$ & Cukup \\
2 & $66-72$ & 6 & $20.7 \%$ & Baik \\
3 & $73-79$ & 3 & $10.35 \%$ & Baik \\
4 & $80-86$ & 8 & $27.6 \%$ & Baik Sekali \\
5 & $87-93$ & 9 & $31.05 \%$ & Baik Sekali \\
6 & $94-100$ & 2 & $6.9 \%$ & Baik Sekali \\
& Jumlah & 29 & $100 \%$ & \\
\hline
\end{tabular}

Berdasarkan data di atas dapat diketahui nilai Post Test siswa yaitu: 1 responden memperoleh skor disekitar 59-65 sebesar 3.45\%, 6 responden memperoleh skor disekitar 66-72 sebesar $20.7 \%, 3$ responden memperoleh skor sekitar 73-79 sebesar $10.35 \%, 8$ responden memperoleh skor sekitar 80-86 sebesar 27.6\%, 9 responden memperoleh skor 87-93 sebesar $31.05 \%, 2$ responden memperoleh skor sekitar 94100 sebesar $6.9 \%$.

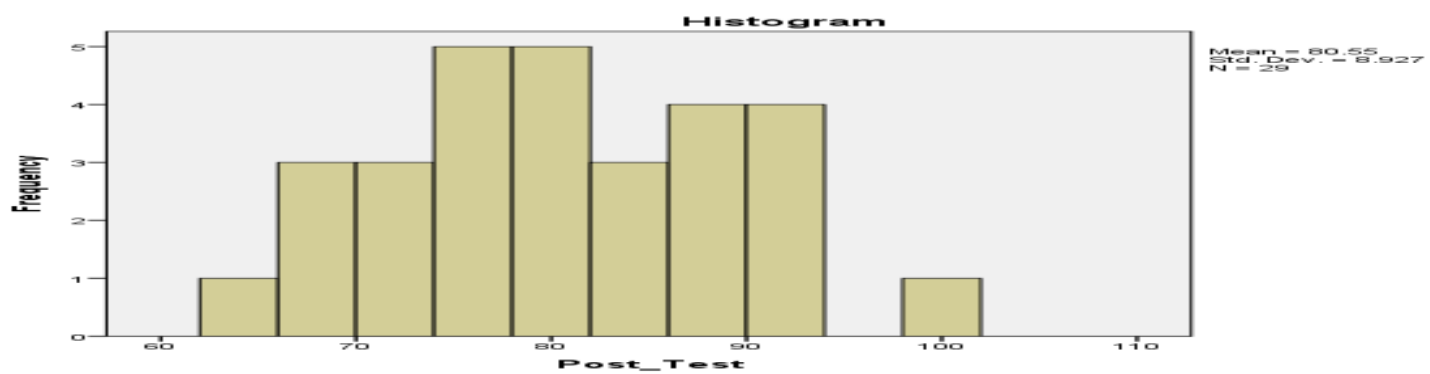

Gambar 2. Histogram Distribusi Frekuensi Nilai Post Test

Berdasarkan histogram distribusi frekuensi nilai Post Test kelas V diperoleh nilai tertinggi adalah 100 dan nilai terendah 64 diperoleh rata-rata (mean) sebesar 80.55 dan standar deviasi sebesar 8.927. Siswa yang memperoleh nilai diatas rata-rata (mean) sebanyak 25 orang dengan persentase $86.25 \%$ dan siswa yang memperoleh nilai dibawah rata-rata (mean) sebanyak 4 orang dengan presentase $138 \%$. Dengan presentase tertinggi sebesar $31.05 \%$ dan persentase terendah sebesar $6.9 \%$.
Hasil nilai Post Test menunjukan bahwa ada peningkatan ketuntasan belajar siswa kelas $\mathrm{V}$ B. Hasil ini dapat dilihat dari nilai Post Test lebih tinggi dari pada nilai Pre Test. Dimana nilai ratarata Post Test 80.55 sedangkan nilai Pre Test 63.72. Untuk lebih jelasnya dapat dilihat dari nilai rata-rata Pre Test dan Post Test pada diagram di bawah ini:

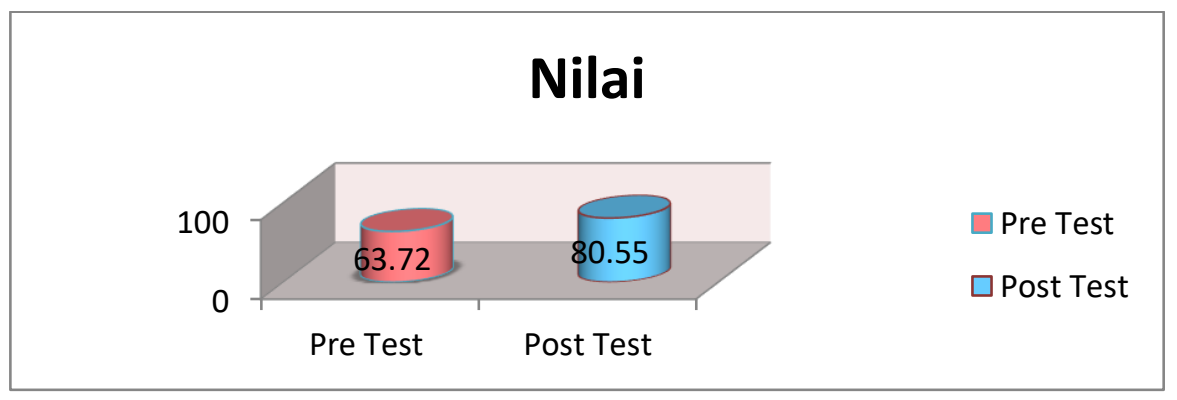

Gambar 3. Diagram Nilai Rata-Rata Pre Test dan Post Test 
Berdasarakan gambar di atas, dapat diketahui nilai rata-rata yang diperoleh sebesar 80.55 dengan kategori baik sekali.

\section{Hasil Angket Kelas V B}

Pada akhir pembelajaran, peneliti memberikan angket kepada siswa hal ini bertujuan untuk mengetahui tingkat keberhasilan dan bagaimana keadaan siswa setelah diberikan pembelajaran dengan menggunakan model pembelajaran Berbasis Masalah. Berdasarkan data yang didapatkan jumlahnya 1557 dengan rata-rata sebesar 53.68 dengan nilai tertinggi yaitu 59 sedangkan nilai terendah yaitu 45 . Mean ideal (Mi) sebesar 53 dengan standar deviasi ideal (SDi) sebesar 3.6. Adapun distribusi frekuensi data tentang hasil angket siswa kelas V B dapat dilihat di bawah ini:

Tabel 4. Distribusi Frekuensi hasil Angket

\begin{tabular}{cccc}
\hline NO & NILAI & Frekuensi & Presentase \\
\hline 1 & $46-48$ & 3 & $10.35 \%$ \\
2 & $49-51$ & 6 & $20.7 \%$ \\
3 & $52-54$ & 4 & $13.8 \%$ \\
4 & $55-57$ & 13 & $44.85 \%$ \\
5 & $58-60$ & 3 & $10.35 \%$ \\
& Jumlah & 29 & $100 \%$ \\
\hline
\end{tabular}

Berdasarkan data di atas dapat diketahui besar presentase hasil Angket siswa yaitu: 3 responden memperoleh skor disekitar 46-48 sebesar $10.35 \%, 6$ responden memperoleh skor disekitar 49-51 sebesar 20.7\%, 4 responden memperoleh skor sekitar 52-54 sebesar 13.8\%, 13 responden memperoleh skor sekitar 55-57 sebesar $44.85 \%, 3$ responden memperoleh skor 58-60 sebesar $10.35 \%$. untuk lebih jelasnya dapat dilihat pada gambar histogram di bawah ini:

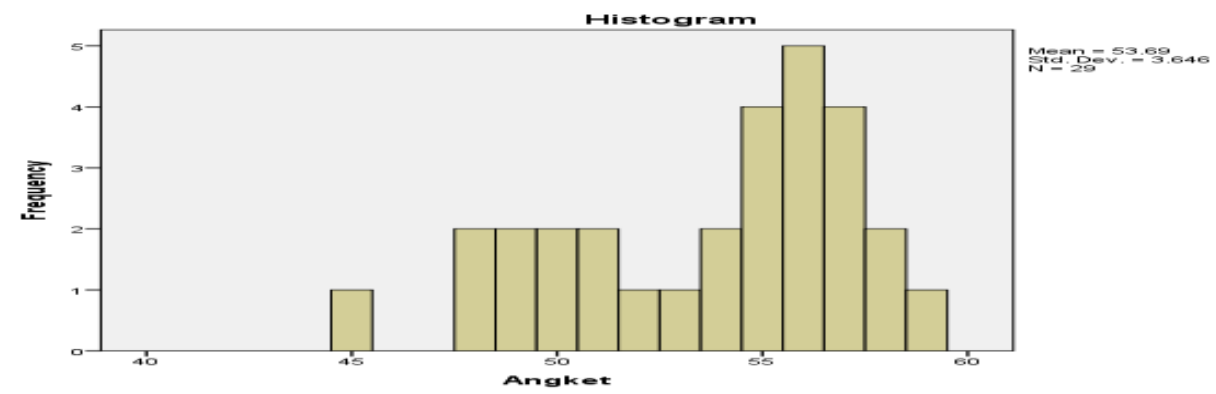

Gambar 4. Histogram Distribusi Frekuensi Hasil Angket

Berdasarkan tabel distribusi frekuensi hasil angket kelas $\mathrm{V}$ diperoleh nilai tertinggi adalah 59 dan nilai terendah 45 diperoleh rata-rata (mean) sebesar 53.68 dan standar deviasi idealnya sebesar 3.6. Dengan presentase tertinggi sebesar $44.85 \%$ dan presentase terendah sebesar $10.35 \%$.

\section{Uji Koofesien Kolerasi}

Uji koefisien kolerasi digunakan untuk mengetahui ada tidaknya pengaruh antara variabel bebas $(\mathrm{X})$ variabel terikat $(\mathrm{Y})$, dan syarat untuk uji koefisien kolerasi yaitu dengan melihat $t_{\text {hitung }}>t_{\text {tabel }}$ dengan rumus kolerasi product moment yaitu: Bahwa untuk melihat pengaruh dari kedua variabel dapat dilakukan dengan membandingkan antara $r_{\text {hitung }}$ dengan $r_{\text {tabel. }}$. Dari perhitungan di atas secara manual dapat dilihat nilai koefisien kolerasi sebesar 0.852. Sedangkan uji koefisien korelasi berbantuan SPSS ver 22 pada tabel di bawah ini: 
Tabel 5. Correlations

\begin{tabular}{llll}
\hline \multirow{3}{*}{ Model PBM } & & Model PBM & Berpikir Kritis \\
& Pearson Correlation & 1 & $.852^{* *}$ \\
\cline { 2 - 4 } Berpikir Kritis. (2-tailed) & & .000 \\
& $\mathrm{~N}$ & 29 & 29 \\
& Pearson Correlation & $.852^{* *}$ & 1 \\
& Sig. (2-tailed) & .000 & \\
& $\mathrm{~N}$ & 29 & 29 \\
\hline
\end{tabular}

Dari tabel di atas menunjukkan bahwa nilai koefisien kolerasi sebesar 0.852 . Jika $\mathrm{r}_{\text {hitung }}>$ $\mathrm{r}_{\text {tabel }}, \mathrm{r}_{\text {htung }}(0.852)>\mathrm{r}_{\text {tabel }}(0.367)$. Maka terdapat pengaruh yang sangat kuat antara model pembelajaran Berbasis Masalah terhadap keterampilan berpikir kritis siswa. Dapat disimpulkan terdapat pengaruh yang sangat kuat antara model pembelajaran Berbasis Masalah terhadap keterampilan berpikir kritiis siswa kelas V SD Negeri 067245 Bunga Asoka sebesar 85.2\%. Dan sebanyak $14.8 \%$ dipengaruhi oleh faktor lain yang tidak dikaji dalam penelitian ini.

\section{Uji Hipotesis}

Setelah data dinyatakan berdistribusi normal dan sampel dari populasi yang sama atau homogen, maka selanjutnya dapat dilakukan pengujian hipotesis menggunakanan "uji $t$ ". statistic yang digunakan untuk menguji hipotesis penelitian adalah uji-t. hipotesis yang diajukan adalah:

$\mathrm{Ha}$ :Terdapat pengaruh model pembelajaran Berbasis Masalah terhadap keterampilan berpikir kritis siswa.

Ho :Tidak terdapat pengaruh model pembelajaran Berbasis Masalah terhadap keterampilan berpikir kritis siswa.

Kriteria uji-t dapat dikatakan apabila diperoleh harag $\mathrm{p}<0.05$. Serta hipotesis diterima $\left(\mathrm{H}_{\mathrm{a}}\right)$ jika $\mathrm{t}_{\text {hitung }}>\mathrm{t}_{\text {tabel }}$ dan ditolak $\left(\mathrm{H}_{\mathrm{o}}\right)$ jika $\mathrm{t}_{\text {hitung }}<$ $t_{\text {tabel }}$ Hasil perhitungan hipotesis uji $t$ dapat dilihat pada tabel 6 di bawah ini:

Tabel 6. Coefficients ${ }^{a}$

\begin{tabular}{|c|c|c|c|c|c|c|}
\hline \multirow[b]{2}{*}{ Model } & & \multicolumn{2}{|c|}{$\begin{array}{l}\text { Unstandardized } \\
\text { Coefficients }\end{array}$} & \multicolumn{2}{|l|}{$\begin{array}{l}\text { Standardized } \\
\text { Coefficients }\end{array}$} & \multirow[b]{2}{*}{ Sig. } \\
\hline & & $\mathrm{B}$ & Std. Error & Beta & $\mathrm{t}$ & \\
\hline 1 & (Constant & -31.523 & 13.249 & & -2.379 & .025 \\
\hline & $\begin{array}{l}\text { Model } \\
\text { PBM }\end{array}$ & 2.087 & .246 & .852 & 8.478 & .000 \\
\hline
\end{tabular}

Untuk mengetahui ada atau tidaknya pengaruh dapat dilihat hasil signifikan yang diperoleh $0.000<0.05$. Hasil perhitungan uji-t dari SPSS ver 22 sebesar 8.478. Untuk mendukung hasil uji-t dari SPSS ver 22, maka berikut hasil uji-t secara manual. Dapat diketahui dari nilai $\mathrm{t}_{\text {hitung }}>\mathrm{t}_{\text {tabel }}$ yaitu $8.478>1.703$ yang artinya ada pengaruh model pembelajaran
Berbasis Masalah terhadap keterampilan berpikir kritis siswa. Berdasarkan perhitungan hasil penelitian terdapat nilai rata-rata antara Pre Test tidak menggunakan model pembelajaran Berbasis Masalah dan Post Test Menggunakan model pembelajaran Berbasis Masalah. Hal ini dapat dilihat pada tabel dibawah ini:

Tabel 7. Hasil Nilai Rata-Rata Pre Test dan Post Test

\begin{tabular}{cccc}
\hline NO & Jenis Perlakuan & Rata-rata & Katergori \\
\hline 1 & Pre Test & 63.72 & Cukup \\
2 & Post Test & 80.55 & Baik Sekali \\
\hline
\end{tabular}


Nilai hasil belajar siswa pada kelas V B mengalami peningkatan, hal ini ditunjukkan dari pengaruh nilai rata-rata Pre Test dan Post Test. Pre Test menunjukkan nilai rata-rata 63.72 dengan kategori cukup sedangkan Post Test rata-ratanya
80.55 dengan kategori baik sekali. Untuk lebih jelas mengenai pengaruh hasil nilai rata-rata Pre Test dan Post Test dapat dilihat pada diagram batang dibawah ini:

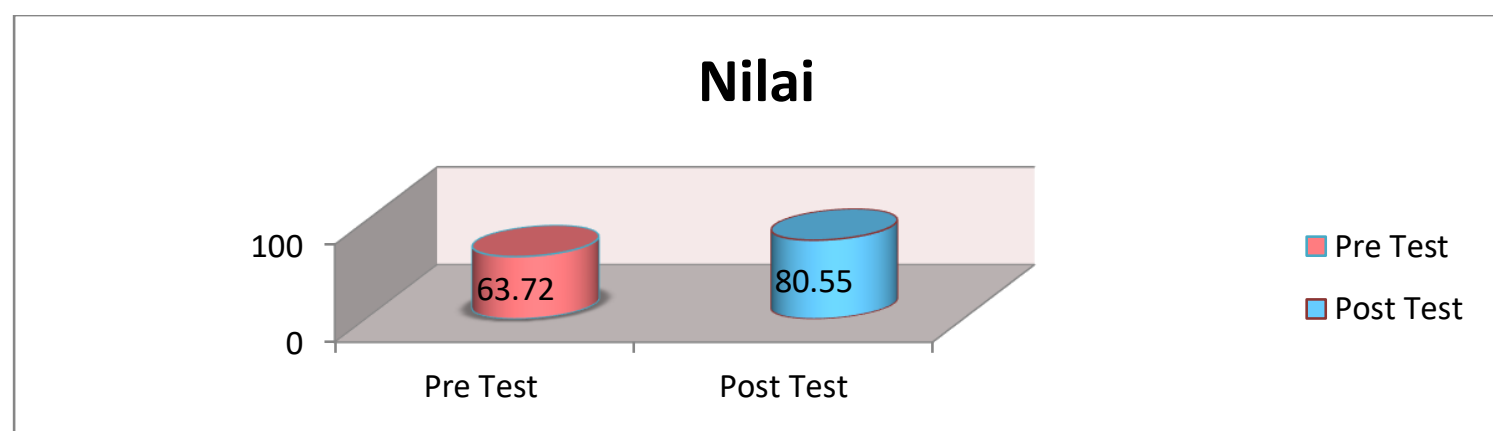

Gambar 5 . Nilai Rata-Rata

Dari uji analisis hipotesis yaitu nilai $t_{\text {hitung }}$ $>\mathrm{t}_{\text {tabel }}$ maka hasil perhitungan yang didapat oleh peneliti yaitu $8.478>1.703$ yang artinya model pembelajaran Berbasis Masalah dinyatakan bahwa hipotesis diterima. Hal ini dibuktikan dari perbedaan hasil Pre Test dan Post test hasil belajar siswa (80.55 > 63.72) pada Tema Lingkungan sahabat kita dan subtema manusia dan lingkungan nya di SD Negeri 067245 Bunga Asoka.

\section{Pembahasan}

Penelitian ini dilakukan dikelas V SD Negeri 067245 Bunga Asoka. Untuk mengetahui kemampuan awal siswa, penelitian melakukan Pre Test dengan jumlah soal pilihan berganda, dan dengan jenis soal yang sama, diperoleh hasilnya dengan rata-rata 63.72 dapat dikatakan kemampuan awalnya cukup. Setelah melakukan Pre Test, peneliti menyampaikan materi dengan menggunakan model pembelajaran Berbasis Masalah. Di akhir pembelajaran, peneliti kembali memberikan Post Test untuk mengetahui tingkat keberhasilan. Hasil dari Post Test tersebut memiliki peningkatan dari hasil Pre Test yang diberikan sebelumnya. Hasil Post Test yang sudah diujikan sebesar 80.55 dapat dikatakan tingkat keberhasilan keterampilan berpikir kritisnya meningkat.

Hasil uji normalitas pada taraf signifikansi $(\alpha=0.05)$, dengan kriteria pengujian normalitas yaitu $\mathrm{L}_{\text {hitung }}<\mathrm{L}_{\text {tabel }}$ maka data berdistribusi normal dengan hasil $\mathrm{L}_{\text {hitung }}=0.074<\mathrm{Ltabel}=0.167$ maka data dapat dikatakan berdistribusi normal. Hasil koefisien korelasi membuktikan bahwa adanya pengaruh model pembelajaran Berbasis Masalah (X) terhadap keterampilan berpikir kritis (Y) dengan hasil $r_{\text {hitung }}>r_{\text {tabel }}$ dengan hasil $0.852>$ 0.367. Pada uji hipotesis dengan menggunakan uji$\mathrm{t}$ dari perhitungan data yang dilakukan, hasil pengujian yaitu $t_{\text {hitung }}>t_{\text {tabel }}$ hasilnya $8.478>1.703$ dengan taraf signifikan $(\alpha=0.05)$. Dengan ini membuktikan bahwa adanya pengaruh yang signifikan dari penggunaan model pembelajaran Berbasis Masalah terhadap keterampilan berpikir kritis siswa pada tema lingkungan sahabat kita kelas V SD Negeri 067245 Bunga Asoka. Berdasarkan hasil data yang diperoleh dari penelitian di SD Negeri 067245 Bunga Asoka dapat dikatakan bahwa dengan model pembelajaran Berbasis Masalah sangat efektif dalam pembelajaran tematik di kelas.

\section{SIMPULAN DAN REKOMENDASI}

Model pembelajaran Berbasis Masalah terhadap keterampilan berpikir kritis siswa kelas V SD Negeri 067245 Bunga Asoka Tahun Pembelajaran 2020/2021 bahwa pada kelas V B dengan materi pembelajaran tema Lingkungan sahabat kita Subtema manusia dan lingkungan pembelajaran 2 di SD Negeri 067245 Bunga 
Asoka Tahun Pembelajaran 2020/2021 kelas V B adalah nilai rata-rata Pre Test 63.72 dengan kategori cukup. Pada kelas $\mathrm{V}$ B dengan menggunakan model pembelajaran Berbasis Masalah pada mata materi tema Lingkungan sahabat kita Subtema manusia dan lingkungan pembelajaran 2 di SD Negeri 067245 Bunga Asoka Tahun Pembelajaran 2020/2021 kelas V B adalah nilai rata-rata Post Test 80.55 dengan kategori baik sekali. Pada kelas V B dengan menggunakan model pembelajaran Berbasis Masalah pada mata materi tema Lingkungan sahabat kita Subtema manusia dan lingkungan pembelajaran 2 di SD Negeri 067245 Bunga Asoka hasil angket siswa rata-rata Angket Test 53.68 dengan kategori sangat tinggi.

Berdasarkan hasil normalitas dengan menggunakkan Uji Lilliefors dengan hasil $\mathrm{L}_{\text {hitung }}=$ $0.074<$ Ltabel $=0.167$ yang dapat dikatakan data berdistribusi normal. Berdasarkan pengujian koefisien korelasi dapat dilihat bahwa nilai koefisien korelasi sebesar 0.852 artinya $\mathrm{r}_{\text {hitung }}$ $(0.852)>\mathrm{r}_{\text {tabel }}(0.367)$. Maka terdapat pengaruh yang kuat dan terdapat pengaruh model pembelajaran Berbasis Masalah Terhadap keterampilan berpikir kritis di kelas V SD Negeri 067245 Bunga Asoka. Dan berdasarkan perhitungan hasil penelitian menunjukkan bahwa terdapat pengaruh model Pembelajaran Berbasis Masalah terhadap keterampilan berpikir kritis siswa pada tema lingkungan sahabat kita kelas kelas V SD Negeri 067245 Bunga Asoka Tahun Pembelajaran 2020/2021 dengan $t_{\text {hitung }}>t_{\text {tabel }}$ dimana $8.478>1.703$ pada taraf signifikan $\alpha=$ 0.05. Siswa dengan tema Lingkungan sahabat kita sub tema manusia dan lingkungan. Dengan demikian $\mathrm{H}_{\mathrm{a}}$ diterima dan $\mathrm{H}_{\mathrm{o}}$ ditolak. Penelitian yang dilakukan oleh peneliti dengan menerapkan model pembelajaran Berbasis Masalah juga dapat meningkatkan Keterampilan berpikir kritis siswa pada tema Lingkungan sahabat kita subtema manusia dan lingkungan di kelas V SD Negeri 067245 Bunga Asoka Tahun Pembelajaran 2020/2021.

\section{DAFTAR PUSTAKA}

Arikunto, S. (2018). Prosedur Penelitian. Jakarta: PT Rineka Cipta.
Aunurrahman. (2014). Belajar dan Pembelajaran. Bandung: Alfabeta.

Dian. (2010). Teori Keterampilan. Pengetahuan dan Keterampilan, 7-26.

Fathurrohman, M. (2015). Model-Model Pembelajaran Inovatif. Jogjakarta: ArRuzz Media.

Hamdani. (2018). Strategi Belajar Mengajar. Bandung: Pustaka Setia.

Hasan, R. \& Syatriandi, B. (2018). Pengaruh Model Pembelajaran Berbasis Masalah (PBM) Terhadap Kemampuan Berpikir Kritis dan Hasil Belajar Biologi Siswa SMA Negeri 06 Kota Bengkulu. Prosiding Seminar Nasional Simbiosis III, (September): 329-341.

Hidayah, N., Pgmi, J., Tarbiyah, F. \& Keguruan, D. (2015). Pembelajaran Tematik Integratif Di Sekolah Dasar Nurul. Terampil Pendidikan dan Pembelajaran Dasar, 2: 34-49.

Kurniawan, D. (2014). Pembelajaran Terpadu Tematik (Teori, Praktik, dan Penilaian). Bandung: Alfabeta.

Manullang, M.T., Silaban, P.J. \& Sitepu, A. (2021). Pengaruh Model Auditory , Intellectualy. Repetition, 6(2), 469-474.

Mudhakir, S. (2013). Peningkatan Kemampuan Berpikir, Slamet Mudhakir, FKIP UMP, 2013. (2011): 5-14.

Ngadirejo, K., Guna, D., Tugas, M., Kuliah, M., Proposal, S. \& Setyaningsih, D. (2016). Pengaruh Model Problem Based Learning Berbasis Science Edutainment Terhadap Kemampuan Berpikir Kritis Siswa SMP.

Nuraini, F. \& Kristin, F. (2017). Penggunaan Model Problem Based Learning (Pbl) Untuk Meningkatkan Hasil Belajar Ipa Siswa Kelas 5 Sd. E-Jurnal mitra pendidikan, 1(4): 369-379.

Prameswari, S.W., Suharno, S. \& Sarwanto, S. (2018). Inculcate Critical Thinking Skills in Primary Schools. Social, Humanities, and Educational Studies (SHEs): Conference Series, 1(1): 742-750.

Pulungan, I. dan I. (2018). Ensiklopedi Pendidikan. Medan Sumatera Utara: Larispa.

Pusparini, S. T. (2017). Pengaruh Model Pembelajaran Problem Based Learning 
Jurnal PAJAR (Pendidikan dan Pengajaran)

Volume 5 Nomor 6 November | ISSN Cetak : 2580 - 8435| | ISSN Online : 2614 - 1337

DOI : http://dx.doi.org/10.33578/pjr.v5i6.8483

(PBL) Terhadap Kemampuan Berpikir Kritis Siswa pada Materi Sistem Koloid. JRPK: Jurnal Riset Pendidikan Kimia, .

Reta, I. (2012). Pengaruh Model Pembelajaran Berbasis Masalah Terhadap Keterampilan Berpikir Kritis Ditinjau Dari Gaya Kognitif Siswa. Jurnal Pendidikan dan Pembelajaran IPA Indonesia, 2(1): 1-17.

Ria Mustika, Pramudiyanti, R. R. T. M. (2014). Pengaruh Pembelajaran Berbasis Masalah Terhadap Kemampuan Berpikir Kritis Siswa. Journal of Chemical Information and Modeling, 53(9): 1689-1699.

Rusman. (2019). Model-model Pembelajaran Mengembangkan Profesionalisme Guru. Jakarta: Rajawali Pers.

Sani, R. A. (2018). Pembelajaran Saintifik untuk Implementasi Kurikulum 2013. Jakarta: Bumi Aksara.

Sanjaya, W. (2014). Penelitian Pendidikan: Jenis, Metode dan Prosedur. Jakarta: Kencana.

Shoimin, A. 2019. 68 Model Pembelajaran Inovatif dalam Kurikulum 2013. Yogyakarta: Ar-Ruzz Media.

Silaban, P. J. (2019). Penerapan Model Pembelajaran Inkuiri untuk Meningkatkan Hasil Belajar Siswa pada Mata Pelajaran Matematika di Kelas VI SD Negeri 066050 Medan Tahun Pembelajaran 2018/2019. Jurnal Ilmiah Aquinas, 2(1): 107-126.

Slameto. (2019). Belajar dan Faktor-faktor yang Mempengaruhi. Jakarta: Rineka Cipta.

Sugiyono. (2018). Metode Penelitian Pendidikan. Bandung: Alfabeta.

Sugiyono. (2019). Metode Penelitian Kuantitatif, Kualitatif. Bandung: Alfabeta.

Sukroni. (2014). Pengaruh Model Problem Based Learning Terhadap Keterampilan Berpikir Kritis Siswa SD N 1 Sajira pada Mata Pelajaran IPA Konsep Ekosistem. Jurnal Pendidikan dan Pembelajaran Sains Indonesia (JPPSI), 2(2): 127.

Surip, M. (2014). Berpikir Kritis Analisis Kajian Filsafat Ilmu. Jakarta: Halaman Moeka Publishing.

Susanto, A. (2018). Teori belajar dan pembelajaran di sekolah dasar. Jakarta: Prenadamedia group. 